\title{
Studies on the Vertical Distribution of Ticks of Domestic Animals and Their Public Health Importance in Nilgiri Hills and Adjoining Areas of Tamil Nadu State (India)
}

\author{
Kaushal Kumar, ${ }^{1}$ N. Balakrishnan, ${ }^{2}$ and Abhay Kumar Sharma ${ }^{1}$ \\ ${ }^{1}$ Centre for Medical Entomology \& Vector Management, National Centre for Disease Control, 22 Sham Nath Marg, Delhi 110054, India \\ ${ }^{2}$ NCDC-Bangalore Branch, 8 NTI Campus, Bellary Road, Bangalore, Karnataka 560003, India \\ Correspondence should be addressed to Abhay Kumar Sharma; drabhayncdc@gmail.com
}

Received 3 July 2014; Revised 26 August 2014; Accepted 26 August 2014; Published 10 September 2014

Academic Editor: Greg Demas

Copyright (C) 2014 Kaushal Kumar et al. This is an open access article distributed under the Creative Commons Attribution License, which permits unrestricted use, distribution, and reproduction in any medium, provided the original work is properly cited.

\begin{abstract}
The Nilgiri hills and adjoining downhill areas provide favourable ecological conditions for the propagation of haematophagous arthropods owing to richness in vegetation and animal activities. A study has been undertaken during 2008-2010 on the distribution and abundance of ticks of domestic animals in seven different biotopes. A total of 3,008 domestic animals were examined in areas ranging from an altitude of 300 to 2200 meters above mean sea level (MSL) of which 1,335 (44.5\%) animals were having tick infestation. A total of 6,012 adult and immature ticks belonging to 12 species (11 ixodid and one argasid) were collected. Eleven tick species were collected from Kallar area situated downhill eastern slopes of the Nilgiris followed by Burliar area ( 7 species) located at higher altitudes. From Masinagudi area near to dense forests and scrub jungles, five species were recorded. However, at higher elevations on the hills, Udhagamandalam area, only one species was recorded. Among various tick species recorded in the study, Boophilus microplus was distributed in almost all areas surveyed followed by Haemaphysalis spinigera and Rhipicephalus sanguineus. The factors governing their distribution and epidemiological significance in the transmission of various tick-borne diseases of public health importance are discussed.
\end{abstract}

\section{Introduction}

Ticks (Acari: Ixodoidea) next to mosquitoes are involved in the transmission of a variety of disease pathogens of public health and veterinary importance since time immemorial. However, the studies on tick-borne diseases gained momentum in the world after the outbreak of Rocky Mountain spotted fever (RMSF) in the United States during the second half of the nineteenth century. In India, the studies of ticks received importance after the discovery of Kyasanur Forest disease (KFD) transmitted by Haemaphysalis spp. in Shimoga district of Karnataka state in 1957 [1]. A report by Pattnaik (2006) indicates the increasing number of KFD cases in Karnataka and necessitates the strategic control of tick vectors [2]. Thereafter, sporadic cases of indigenous/imported nature were reported from different parts of the country time to time. During 2007, a full bloom epidemic of Indian tick typhus was reported from village Deol district Kangra (Himachal Pradesh), wherein 357 cases reported a population of 1223 [3]. During 1994, serologically positive cases of Lyme disease were reported from Coonoor in Nilgiri Hills of Tamil Nadu state [4]. Shanmugam et al. [5] have reported the presence of Crimean-Congo haemorrhagic fever (CCHF) virus infection in human and domestic animals from various parts of India. However, the first instance of CCHF was detected from Kolat village near Ahmadabad in January 2011 and subsequently cases/deaths are reported from Mehsana district and nearby area in 2012 and 2013 [6]. In the last three years, there have been 30 positive cases and 14 deaths due to CCHF in Gujarat [7]. Increasing public health concern over tick-borne diseases in recent years necessitates strategic control of ticks on animals that transmit diseases to human beings. In view of the above, a comprehensive study has been undertaken on the ectoparasitic ticks on domestic 
animals and their vertical distribution in Nilgiri hills and its surroundings and their probable role in the transmission of various diseases of public health importance.

\section{Material and Methods}

2.1. Study Area. The study area is comprised of the Nilgiri hills lying in Udhagamandalam and the eastern down hills and adjoining areas under the Coimbatore districts of Tamil Nadu state. The above area is situated at an altitude ranging from 300 to 2000 meters above mean sea level (MSL) in the latitude $11^{\circ}, 10^{\prime} \mathrm{N}$ and longitude $76^{\circ}, 5^{\prime} \mathrm{E}$. The mountainous areas of Nilgiris owing to higher altitude have higher precipitation throughout the year with peaks in June/July and October/November. The above areas have the impact of both South West (SW) and North East (NE) monsoons with an annual rainfall of $1200 \mathrm{~mm}$. The above areas have temperature ranging from $2^{\circ} \mathrm{C}$ to $28^{\circ} \mathrm{C}$ and have temperate or equitable type of climate with abundant vegetation, whereas the downhill areas have tropical type of climate with temperature ranging from $16^{\circ} \mathrm{C}$ to $37^{\circ} \mathrm{C}$. The rainy season is mainly due to NE monsoon with peaks in October/November with an average rainfall of $500 \mathrm{~mm}$.

2.2. Description of Various Biotopes in the Study Area. The brief description of various biotopes surveyed, their location, altitude, and vegetation forest cover are as follows.

(i) Mettupalayam and Adjoining Villages. The above locality has typical characteristic features of downhill areas having human inhabitations surrounded by agricultural lands and situated near Nilgiri hills.

(ii) Kallar and Surroundings. This area is situated in the eastern slope of Nilgiris hills and having scrub jungle surrounded by spice gardens, areca nut grooves, and agricultural land with wild animal activities.

(iii) Burliar and Surroundings. This area is situated in eastern slopes of Nilgiri hills in the elevation of 900 to 1600 metres above MSL. It is characterized by typical mountainous climate with wild animal activity and having coffee/tea plantation and fruits orchards.

(iv) Coonoor and Surroundings. They are situated in the altitude of 1600 to 1900 meters above MSL. This area is having human inhabitations surrounded with tea plantations and vegetable gardens.

(v) Udhagamandalam and Surroundings. This area is situated at higher elevations of the Nilgiri hills with an altitude ranging from 1900 to 2200 metres above MSL. The above areas have human inhabitations surrounded by meadows, vegetable gardens.

(vi) Gudalur and Surroundings. These areas are situated in the western slope of the Nilgiri hills at an elevation of 1100 to 1200 metres above MSL and are characterized by the presence of human inhabitations surrounded by coffee/tea plantations and other agricultural crops.

(vii) Masinagudi and Surroundings. This area is having dense jungles and scrub jungle and surrounded by grassing lands and agricultural lands located in altitude of 1000 to 1200 metres above MSL with wild animal activity and a few human inhabitations. The altitudes of the locality influence the climate and vegetation and also have a bearing on the distribution and abundance of haematophagous ticks.

2.3. Host Availability. The study area has forest fringed sectors/horticultural plantations/orchards and agricultural lands having wild animals' activities. However, the survey included the domestic animals, namely, cattle (Bos indicus), goat (Capra hircus), sheep (Ovis aries), buffalo (Bubalus bubalis), dog (Canis familiaris), and horse (Equus caballus) for the infestation of ectoparasitic ticks. The tick collections were made in seven different biotypes situated in the study area and the description regarding their location and altitude is given in Table 1 .

2.4. Tick Collection. In each biotope, villages were selected randomly and, with the selected villages, the households were also selected randomly. In each of the selected household, all the available domestic animals were included in the study. Ticks were collected by hand picking method from various animals and thoroughly searched to collect the larva, nymph, and adult ticks. Total of five minutes were spent in collection of ticks on each animal. Ticks thus collected were preserved in $70 \%$ alcohol and identified in the laboratory using standard identification keys and tick prevalence indices; namely, tick infestation rate on host animals and tick index have been computed.

\section{Results}

A total of 3,008 domestic animals, namely, cattle (2,354), goat (500), sheep (100), buffalo (39), dog (13), and horse (2), were searched to see the infestation of ectoparasitic ticks. A total of 6,012 adult and immature ticks belonging to six genera and 12 species (11 ixodid and 1 argasid) were collected from 1,335 domestic animals including 1,095 cattle, 195 goat, 35 sheep, 5 buffalo, and 5 dogs (Table 1). The overall density of tick infestations was calculated as $44.4 \%$ and maximum $46.51 \%$ in cattle. The overall tick index computed during the study was 1.99 and maximum 4.97 in buffalo (Table 2).

Maximum numbers of tick species (eleven) were recorded from Kallar area located in eastern down hills of the Nilgiris and one species (minimum) was recorded from Udhagamandalam and surroundings area situated at higher altitudes of the hills. Three, seven, four, one, three, and five tick species were recorded from Mettupalayam, Burliar, Coonoor, Udhagamandalam, Gudalur, and Masinagudi and surroundings, respectively (Table 1). B. microplus was the widely distributed and also the most prevalent tick species. Haemaphysalis spp. and Rhipicephalus spp. were distributed in eastern western slopes of the Nilgiris and absent in 


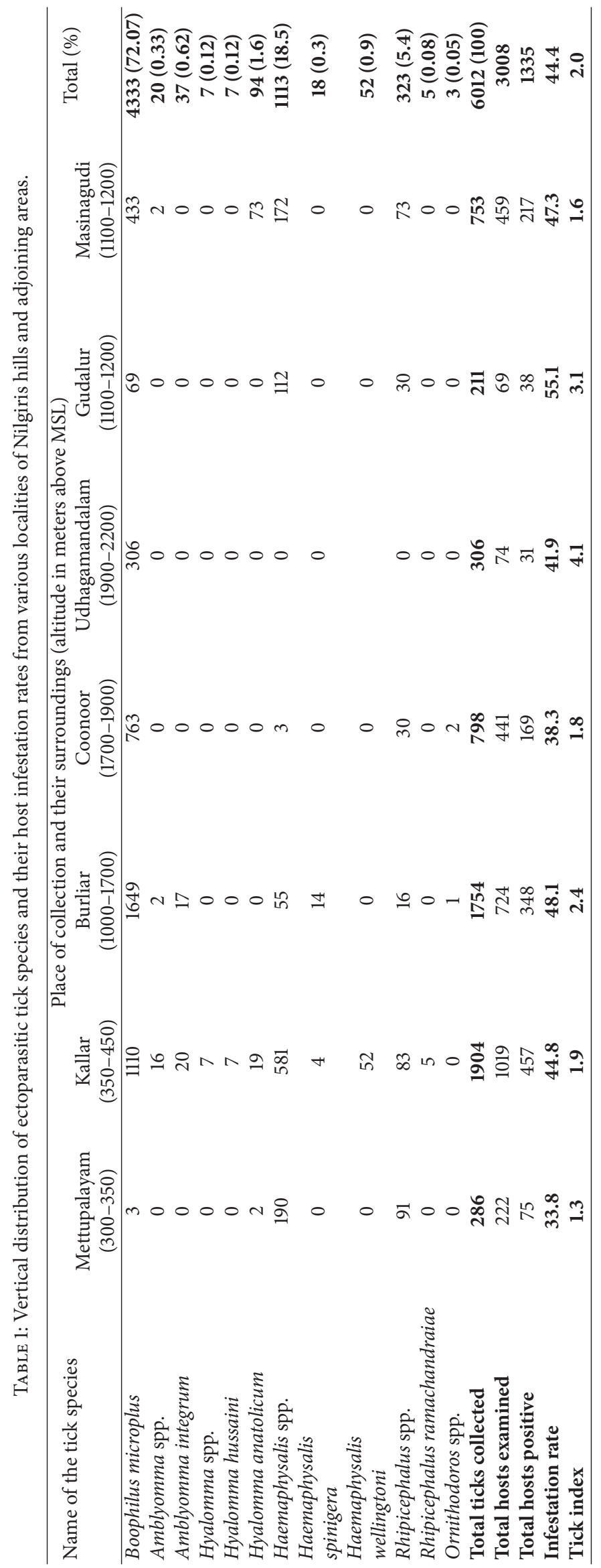


TABLE 2: Tick infestation rate and tick index in Nilgiri hills study area.

\begin{tabular}{lccccc}
\hline & Host animal & Number searched/found +ve & Tick infestation rate & Number of ticks Collected & Tick index \\
\hline 1 & Bos indicus & $2354 / 1095$ & 46.51 & 4974 & 2.11 \\
2 & Capra hircus & $500 / 195$ & 39.0 & 733 & 80 \\
3 & Ovis aries & $100 / 35$ & 35.0 & 1.5 & 0.8 \\
4 & Bubalus bubalis & $39 / 5$ & 12.82 & 31 & 2.97 \\
5 & Canis familiaris & $13 / 5$ & 38.46 & 0 & 0 \\
6 & Equus caballus & $2 / 0$ & 0.0 & $\mathbf{6 0 1 2}$ & $\mathbf{1 . 9 9}$ \\
\hline
\end{tabular}

higher altitudes above $1900 \mathrm{mts}$ MSL. Hyalomma spp. and Amblyomma spp. were recorded only in Kallar and Burliar areas in eastern slopes of the Nilgiris areas. Ornithodoros ticks were recorded in limited numbers from two localities of the eastern slopes (Burliar and Coonoor) in the altitude ranging from 1000 to $1900 \mathrm{mts}$ MSL. The particulars of tick genera recorded and their percentage composition from different biotopes/localities of the study area are given Table 1.

Tick infestation rate in relation to host animals ranged from 33.8 (Mettupalayam villages) to 55.1 (Gudalur and surroundings). Tick infestation rates show higher values in both eastern and western slopes and down hills than in higher altitudes and plain area villages. Tick index computed for the total study area is 2.0 and it showed a maximum value in Udhagamandalam area (4.1) and was minimum (1.3) in Mettupalayam villages. High value of tick index was recorded at higher altitudes than plain areas.

\section{Discussion}

The present studies on the vertical distribution and prevalence of ticks are mainly attributed to the altitude, vegetation, animal activity, host availability, and other climatic factors in the study area. The Nilgiri hills provide favourable ecological conditions for the propagation of haematophagous arthropods including ticks due to its richness in vegetation and animal fauna. Earlier at higher altitudes of Nilgiri hills, Kumar et al. [8] determined the epidemiological significance of ixodid ticks and recorded B. microplus, H. bispinosa, Riphicephalus haemaphysaloides, and $R$. sanguineus from domestic animals. Earlier studies in other parts of India pointed out the importance of various factors responsible for the distribution and abundance of ticks. In Mathura district, Uttar Pradesh (India), Patel et al. [9] observed the prevalence and seasonal variation in ixodid ticks on cattle and recorded highest tick infestation in rainy season (69.46\%), followed by summer $(62.55 \%)$ and lowest infestation was recorded in the winter (47.96\%) season. Singh and Rath [10] determined the epidemiology of ixodid ticks in bovines of different agroclimatic zones of Punjab state, India, and observed highest prevalence of ixodid ticks in monsoon season (83.74\%), followed by summer (69.01\%) and least in winters (31.64\%), whereas maximum prevalence of $R$. microplus and $H$. $a$. anatolicum was recorded in monsoon (72.42\%) and summers
(18.06\%), respectively. Mehta [11] recorded Hyalomma spp., R. sanguineus, $R$. haemaphysaloides, Haemaphysalis spp., and Ixodes spp. from Shimla hills and described their possible role in disease transmission. Dhanda and Rao [12] collected Ixodid ticks from North East Frontier Agency (India) and stratified areas based on the distribution of 1,656 ticks belonging to 7 genera and 17 species. They classified areas in (i) warmer region-tropical evergreen forests, (ii) colder and higher altitudes, and (iii) species occurring in both colder and warmer altitudes. Varma and Mahadevan [13] reported ixodid tick fauna in eastern Himalayas and their disease relationship potential and recorded 7 genera and 14 species of ixodid ticks. Amblyomma spp. and B. microplus were recorded in large numbers. Kaul et al. [14] in Jammu and Kashmir of India recorded ixodid ticks belonging to seven genera and 16 species. In Shimoga district of Karnataka state, a study on the tick fauna has been carried out by Kumar et al. [15], wherein $H$. spinigera on dogs has been recorded from the endemic area of KFD; it is a significant finding as the above hosts facilitate the maintenance of the virus. The other tick species recorded were B. microplus (47.7\%), H. spinigera (40.5\%) H. cornigera (3.31\%), R. sanguineus (8.29\%), and A. integrum (2.07\%). Gandhi et al. [16] carried out an epidemiological investigation of multisource outbreak of CCHF in Gujarat and confirmed the presence of CCHF virus in Hyalomma species of ticks collected from domestic animals. Similarly, the prevalence of ixodid ticks on domestic animals of several other Indian states like Assam, Karnataka, and Tamil Nadu has been already reported by Miranpuri and Singh [17], Jagannath et al. [18], and Latha et al. [19]. Saxena et al. [20] recorded 8 species of ticks from 126 different domestic animals in localities at altitudes ranging from 320 to $2240 \mathrm{~m}$ above sea level. Only 2 of the tick species, B. microplus and R. haemaphysaloides, were found throughout the range of localities. However, in the present study, in addition to the earlier reported tick species, new additions were Rhipicephalus spp., Amblyomma spp., Hyalomma spp., H. hussaini, H. analoticum, H. wellingtoni, and Ornithodorous spp. This was attributed to a large number of host animals from different localities of the study area. A high prevalence of B. microplus was reported from all the altitudes and localities. The downhill areas/slopes in both eastern and western slopes showed the distribution of more tick species than in plain areas and higher elevations. Maximum diversity of tick species were recorded from Kallar locality at altitude 350-450 meters. Bos indicus was the 
most infested host animal for tick with 46.51 infestation rate followed by Capra hircus and Canis familiaris.

The Nilgiri hills are having a diverse terrain features with distinct ecological characteristics having deciduous wet forests or monsoon forests ecosystem. The terrain features and climatic conditions, namely, low temperature, high humidity, high rain fall, and thicker forest cover with large animal population, render this area suitable for the propagation of a wide variety of haematophagous arthropods including ticks.

In India, major tick-borne diseases have been reported from many parts especially hilly and forest fringed areas. One of the most important diseases transmitted by Hyalomma ticks is CCHF, of which H. marginatum is one of the main vector ticks. Rhipicephalus spp. dog tick $R$. sanguineus is reservoir Indian tick typhus and responsible for Indian tick typhus from many parts of the country and also responsible for causing of boutonneuse fever. R. haemaphysaloides is known as the common ectoparasites of many animals of India responsible for a variety of animal diseases and KFD virus has also been isolated from wild caught ticks of this species. Prevalence of vector ticks of KFD, Indian tick typhus, Spotted fever, $\mathrm{CCH}$ fever in the Nilgiris hills and adjoining areas, and seropositivity among human for Lyme disease have been recorded from the study area $[4,21]$. Amblyomma spp. is the vector of $R$. rickettsii and $R$. conorii causing Rock Mountain spotted fever (RMSF) in United States of America and East Africa, respectively $[22,23]$. B. microplus is the pest of cattle and carries many pathogens, namely, Coccinella burnetii, Theileria, and Babesia spp. [24]. It is also the efficient vector of Bovine babesiosis caused by B. bigemina in India which is of veterinary importance [25-27]. In Brazil, it is the potential vector of $R$. rickettsii causing RMSF [28]. Dermacentor spp. are the vectors of looping illness virus, Omsk haemorrhagic fever, Colorado tick fever, and RMSF in the USA [29]. It is also the suspected vector of haemorrhagic toxoplasmosis in eastern Himalayas' foot hill jungles [30]. In nature, Ixodes spp. are responsible for harboring viruses of Russian spring summer encephalitis (RSSE), KFD, and encephalitis in nature [31]. Ixodes ricinus is the vector of Lyme disease in the USA and Europe [32]. In India, KFD and CCHF are both of high importance for public health and KFD virus has been isolated from $H$. spinigera, $H$. turturis, $H$. bispinosa, $H$. cuspidata, H. wellingtoni, and other Ixodes species [33-39]. This study confirms the presence of Boophilus spp., Amblyomma spp., Hyalomma spp., Haemaphysalis spp., Rhipicephalus spp., and Ornithodoros spp. in the study area. This warrants further in depth studies on the exact role of vector ticks in disease transmission, isolation of pathogens in ticks, and serosurveillance in human population in the study area. Present investigations provides necessary information for human and animal health service mangers to have a better understanding of prevention and control of tick borne-diseases especially during the outbreaks.

\section{Conflict of Interests}

The authors do not have any conflict of interests.

\section{References}

[1] T. H. Work, H. Trapido, D. P. Murthy, R. L. Rao, P. N. Bhatt, and K. G. Kulkarni, "Kyasanur forest disease. III. A preliminary report on the nature of the infection and clinical manifestations in human beings," Indian Journal of Medical Sciences, vol. 11, no. 8, pp. 619-645, 1957.

[2] P. Pattnaik, "Kyasanur forest disease: an epidemiological view in India," Reviews in Medical Virology, vol. 16, no. 3, pp. 151-165, 2006.

[3] K. Kumar, S. K. Jain, and A. K. Sharma, "Outbreak of Indian Tick Typhus amongst residents of Deol village, District, Kangra, Himachal Pradesh (India)," International Journal of Medicine and Public Health, vol. 1, no. 3, pp. 67-71, 2011.

[4] R. S. Sharma, T. Verghese, R. S. Gupta, and D. Chattopadhya, "Epidemiology of Lyme disease in the Nilgiri hills-1992-a premilinary report," in Proceedings of the 3rd Symposium of Vectors and Vector Borne Diseases, Haffkine's Institute, Mumbai, India, 1992.

[5] J. Shanmugam, S. E. Smirnova, and M. P. Chumakov, "Presence of antibody to arboviruses of the Crimean Haemorrhagic Fever Congo (CHF Congo) group in human beings and domestic animals in India," Indian Journal of Medical Research, vol. 64, no. 10, pp. 1403-1413, 1976.

[6] The Tropical Medical Bureau, http://www.tmb.ie/destination/ news.asp?title $=42$-under-surveillance-over-Crimean-Congo-Fever-case-in-Indian-State-of-Gujarat\&id=182195.

[7] “Media Scanning \& Verification cell," ISDP, NCDC Delhi, Alert ID No. 2259, 2013.

[8] K. Kumar, N. Balakrishanan, R. Katyal, and K. S. Gill, "Prevalence of ixodid ticks in Nilgiri District of Tamil Nadu State (India)," Journal of Communicable Diseases, vol. 34, no. 2, pp. 124-127, 2002.

[9] G. Patel, D. Shanker, A. K. Jaiswal, V. Sudan, and S. K. Verma, "Prevalence and seasonal variation in ixodid ticks on cattle of Mathura district, Uttar Pradesh," Journal of Parasitic Diseases, vol. 37, no. 2, pp. 173-176, 2013.

[10] N. K. Singh and S. S. Rath, "Epidemiology of ixodid ticks in cattle population of various agro-climatic zones of Punjab, India," Asian Pacific Journal of Tropical Medicine, vol. 6, no. 12, pp. 947-951, 2013.

[11] D. R. Mehta, "Studies on typhus in the Simla hills part viii ectoparasites of rats and shrews with special reference to their possible role in the transmission of typhus," Indian Journal of Medical Sciences, vol. 25, no. 2, pp. 353-365, 1937.

[12] V. Dhanda and T. R. Rao, "A report on collection of Ixodid ticks made in North East Fortien Agency India," Indian Journal of Medical Research, vol. 52, pp. 1139-1153, 1964.

[13] R. N. Varma and B. Mahadevan, "Ixodid ticks collected in the Eastern Himalayas and their potential disease relationships," The Indian Journal of Medical Science, vol. 58, no. 6, pp. 693706, 1970.

[14] H. N. Kaul, P. S. Shetty, G. R. Ghalsasi, and V. Dhanda, "Survey of ticks (Acarina: Ixodidae) for crimean haemorrhagic fever virus activity in Jammu and Kashmir state, India," Indian Journal of Medical Sciences, vol. 91, pp. 5-8, 1990.

[15] K. Kumar, V. K. Sexena, and S. Lal, "Prevalence of vectors of scrub typhus, plague and KFD in district Shimoga, Karnataka state, India," in Vector Borne Diseases: Epidemiology and Control, B. K. Tyagi, Ed., pp. 205-211, Scientific Publishers, Jodhpur on behalf of CRME (ICMR), Madurai, India, 2008. 
[16] S. Gandhi, D. Paresh, G. C. Patel, H. J. Khatri, N. Shah, and U. Mishra, "An epidemiological investigation of a multisource outbreak of Congo Crimean Haemorrhagic fever (CCHF)," Journal of Communicable Diseases, vol. 43, no. 3, pp. 161-167, 2011.

[17] G. S. Miranpuri and J. Singh, “Ticks and mites from domestic animals in Assam, India and their possible role in transmission of diseases," Indian Journal of Parasitology, vol. 2, pp. 11-14, 1978.

[18] M. S. Jagannath, K. Muraleedharan, and L. S. Hiregoudar, "Prevalence of Ixodid ticks of cattle at Bangalore," Indian Journal of Animal Sciences, vol. 49, pp. 890-894, 1979.

[19] B. R. Latha, S. S. Aiyasami, G. Pattabiraman, T. Sivaraman, and G. Rajavelu, "Seasonal activity of ticks on small ruminants in Tamil Nadu State, India," Tropical Animal Health and Production, vol. 36, no. 2, pp. 121-133, 2004.

[20] V. K. Saxena, K. Kaushal, and R. Rajagopal, "Vertical distribution of ticks of domestic animals in Nilgiri hills (Tamil Nadu)," Journal of Communicable Diseases, vol. 16, no. 4, pp. 323-325, 1984.

[21] D. T. Mourya, P. D. Yadav, V. K. Sandhya, and S. Reddy, "Spread of Kyasanur Forest disease, Bandipur Tiger Reserve, India, 20122013," Emerging Infectious Diseases, vol. 19, no. 9, pp. 1540-1541, 2013.

[22] Centers for Disease Control and Prevention, http://www.cdc. gov/ticks/diseases/.

[23] Centers for Disease Control and Prevention, http://www.cdc. gov/ticks/diseases/abroad.html.

[24] S. Ghosh, P. Azhahianambi, and M. P. Yadav, "Upcoming and future strategies of tick control: a review," Journal of Vector Borne Diseases, vol. 44, no. 2, pp. 79-89, 2007.

[25] M. A. Samad, A. S. M. Bari, and S. A. Bashar, "Gross and histopathological studies on bovine babesiosis in Bangladesh," Indian Journal of Animal Sciences, vol. 58, no. 8, pp. 926-928, 1988.

[26] P. B. Rao, N. S. Surendran, and P. V. R. Rao, "Study on outbreaks of babesiosis in sheep in Andhra Pradesh," Indian Veterinary Journal, vol. 66, no. 4, pp. 348-351, 1989.

[27] U. V. Shastri, N. M. Degloorkar, and G. B. Kulkarni, "Bovine babesiosis due to Babesia bovis at Parbhani (Maharashtra) India," Journal of Veterinary Parasitology, vol. 5, no. 1, pp. 2934, 1991.

[28] M. C. Horta, M. B. Labruna, A. Pinter, P. M. Linardi, and T. T. S. Schumaker, "Rickettsia infection in five areas of the state of São Paulo, Brazil," Memórias do Instituto Oswaldo Cruz, vol. 102, no. 7, pp. 793-801, 2007.

[29] F. S. Dahlgren, R. C. Holman, C. D. Paddock, L. S. Callinan, and J. H. McQuiston, "Fatal Rocky Mountain spotted fever in the United States, 1999-2007," The American Journal of Tropical Medicine and Hygiene, vol. 86, no. 4, pp. 713-719, 2012.

[30] H. Hoogstraal and H. Y. Wassef, "Dermacentor (Indocentor) auratus (Acari: Ixodoidea: Ixodidae): hosts, distribution, and medical importance in tropical Asia," Journal of Medical Entomology, vol. 22, no. 2, pp. 170-177, 1985.

[31] WHO, http://www.who.int/biologicals/areas/vaccines/tick_en -cephalitis/en/.

[32] F.-R. Matuschka and A. Spielman, "Loss of Lyme disease spirochetes from Ixodes ricinus ticks feeding on European blackbirds," Experimental Parasitology, vol. 74, no. 2, pp. 151-158, 1992.
[33] D. T. Mourya, P. D. Yadav, and D. Y. Patil, "Highly infectious tick-borne viral diseases: Kyasanur forest disease and CrimeanCongo haemorrhagic fever in India," WHO South-East Asia Journal of Public Health, vol. 3, no. 1, pp. 8-21, 2014.

[34] K. R. P. Singh, K. Pavri, and C. R. Anderson, "Experimental transovarial transmission of kyasanur forest disease virus in Haemaphysalis spinigera," Nature, vol. 199, article 513, 1963.

[35] K. R. Singh, K. M. Pavri, and C. R. Anderson, "Transmission of Kyasanur Forest disease by Haemaphysalis tururis, Haemaphysalis papuanakinneari and Haemaphysalis minuta," The Indian Journal of Medical Research, vol. 52, pp. 566-573, 1964.

[36] K. R. Singh and P. N. Bhatt, "Transmission of Kyasanur Forest disease virus by Hyalomma marginatum isaaci," Indian Journal of Medical Research, vol. 56, no. 4, pp. 610-613, 1968.

[37] K. R. Singh, M. K. Goverdhan, and T. R. Rao, "Experimental transmission of Kyasanur forest disease virus to small mammals by Ixodes petauristae, I. ceylonensis and Haemaphysalis spinigera," The Indian Journal of Medical Research, vol. 56, no. 4, pp. 594-609, 1968.

[38] K. R. Singh, M. K. Goverdhan, and U. K. Bhat, “Transmission of kyasanur forest disease virus by soft tick, argaspersicus (ixodoidea: argasidae)," Indian Journal of Medical Research, vol. 59, no. 2, pp. 213-218, 1971.

[39] U. K. M. Bhat and M. K. Goverdhan, "Transmission of Kyasanur forest disease virus by the soft tick, Ornithodoros crossi," Acta Virologica, vol. 17, no. 4, pp. 337-342, 1973. 

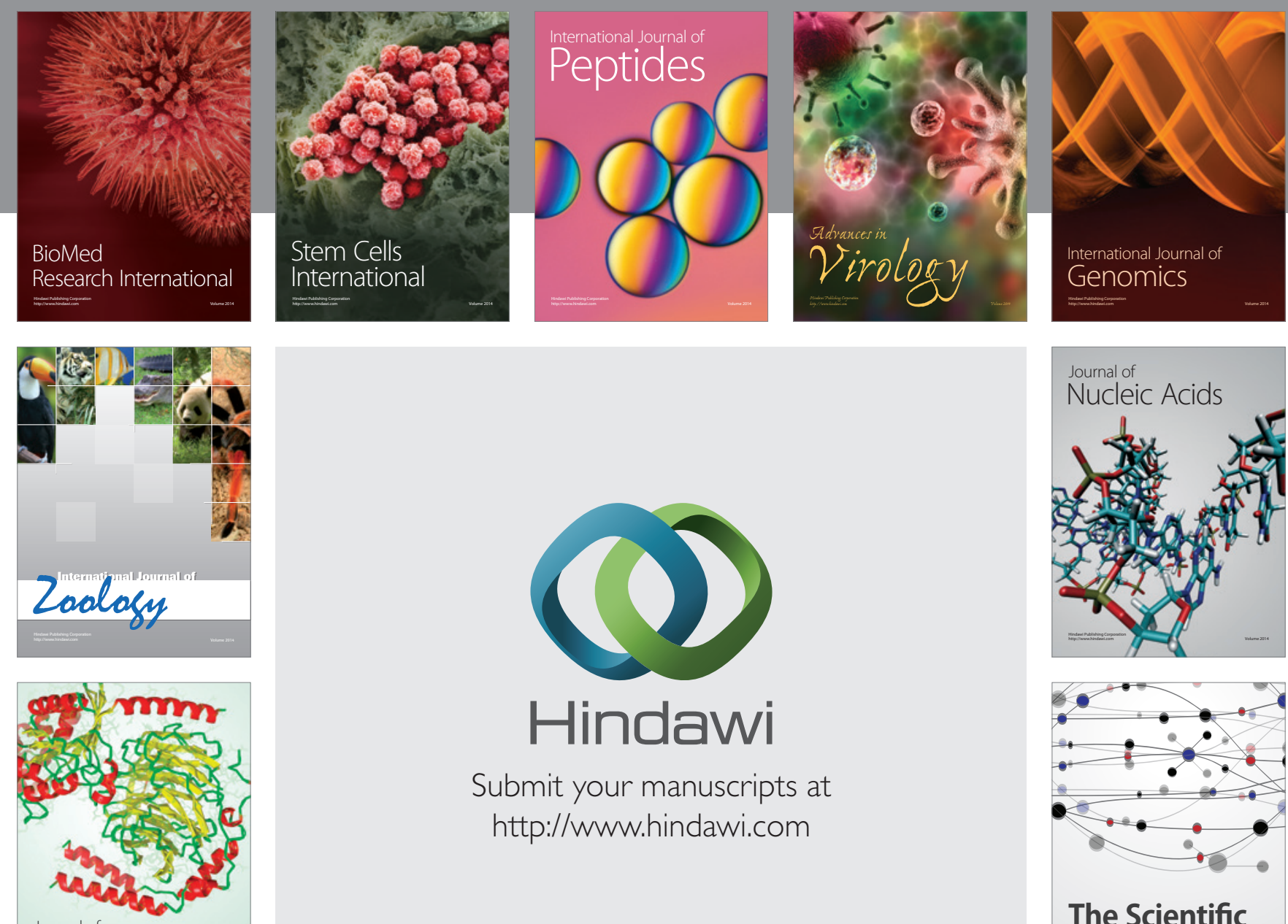

Submit your manuscripts at

http://www.hindawi.com

Journal of
Signal Transduction
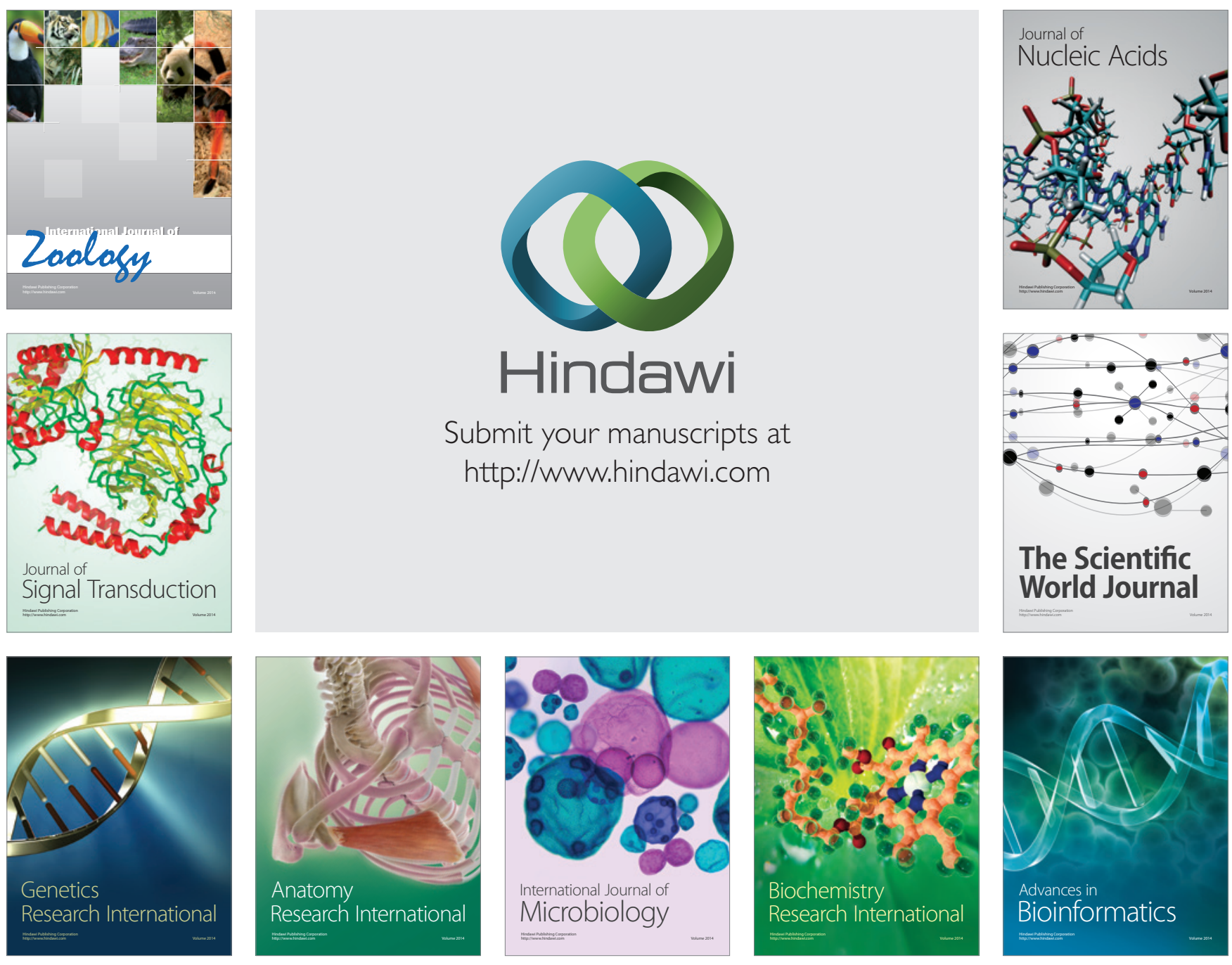

The Scientific World Journal
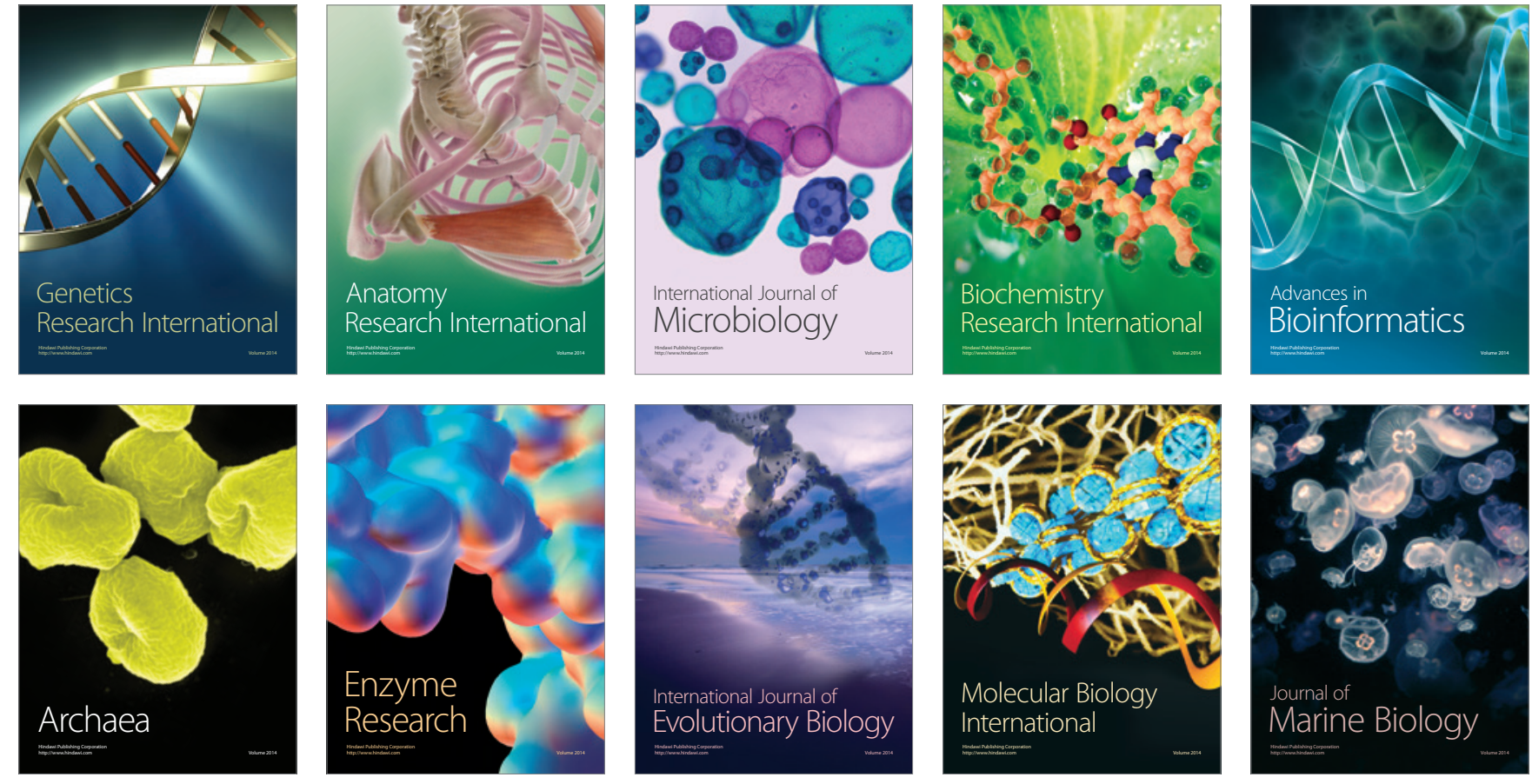